\title{
Financial Development, Economic Growth and Financial Crisis in Asian Emerging Economies
}

\author{
Takashi Fukuda* \\ *Independent Researcher \\ 3-35-13 Kengun, Kumamoto-shi, Kumamoto-ken 862-0911, Japan \\ Tel:81-96-367-0504_E-mail: fukudatakashi4973@gmail.com
}

Received: February 23, 2012 Accepted: March 15, 2012 Published: April 2, 2012

doi:10.5296/rae.v4i2.1429 URL: http://dx.doi.org/10.5296/rae.v4i2.1429

\begin{abstract}
This article examines the causality between financial development, economic growth and financial crisis in India, Indonesia, Korea, Malaysia and Thailand; all these countries are known as emerging economies with well known financial crisis episodes. The summary indicators of financial development, financial crisis and financial repression are created through the principal component method. The cointegration and Granger causality are investigated by using two techniques of vector error correction model (VECM) and autoregressive distributed lag (ARDL). The main findings are: (1) the direction of the finance-growth nexus is a country-specific matter; (2) deeper financial development can lead to financial crisis; and (3) financial crisis has a negative impact on economic growth (except Korea for the last two).
\end{abstract}

Keywords: financial development; economic growth; financial crisis; VECM; ARDL 


\section{Introduction}

Since the seminal works of McKinnon (1973) and Shaw (1973) were published, the finance-growth nexus - how financial development and economic growth interact with each other - has been extensively assessed but the empirical results on this issue have not been reconciled yet. On the other hand, as more economies - in particular those known as emerging economies - have been increasingly exposed to severe financial disturbances over the last few decades, financial crisis has emerged as one of the hottest topics in the literature, highlighting crucial damages on crisis-hit economies. This article attempts to integrate these two subjects or to examine the "finance-growth-crisis" nexus in India, Indonesia, South Korea (hereafter Korea), Malaysia and Thailand. All the countries are known as emerging economies with rapid financial deepening, high economic growth and financial crisis episodes. Since the Chakravarty Committee Report (Report of the Committee to Review the Working of the Monetary System) (Reserve Bank of India, 1985) was announced in April 1985, India was in the process of (partial) financial liberalization experiencing credit boom and high GDP growth over the late 1980s. Then the severe crisis hit that country in early 1991. As described by the term "East Asian miracle" (World Bank, 1993), the high economic achievements of Indonesia, Korea, Malaysia and Thailand had been praised. Their success stories, however, suddenly ended as the Asian crisis came over the period 1997 to 1998. These stories prompt us to examine the "finance-growth-crisis nexus" in these countries. In addition, since the structural break literature was put forward by Perron (1989), the presence of structural break(s) in the growth process (GDP series) is rationally assumed. And inspired by the fact that financial systems in these economies have been controlled to various extents, we are concerned with financial repression. In searching for more plausible estimates, these two elements should be taken into estimation.

Two inherent problems in the literature are pointed out. First, although the relationship between financial deepening and economic growth potentially relates to the incidence of financial crisis, the trivariate linkage of finance-growth-crisis has not been mattered yet, especially in the framework of cointegration and Granger causality. Second, in the empirical literature of finance-growth nexus, the leading evidence - finance exhibits a positive impact on growth - has been drawn from cross-country and panel data models (e.g., King and Levine, 1993). These models, however, implicitly presume homogeneity in different countries' growth patterns and thus mask country-specific factors in estimation (Demetriades and Hussein, 1996; Luintel and Khan, 1999).

The goal of this article is to analyse the cointegration and causality between financial development, economic growth and financial crisis in the five Asian countries through the techniques of the vector error correction model (VECM) and autoregressive distributed lag (ARDL). This article contributes to the literature in three ways. First, we present country-by-country estimates of the finance-growth-crisis nexus in the five Asian countries. Evidence from our study, which takes into account country-specific conditions, will be more plausible than that from a cross-country and panel data study that looks for a single generalized result by averaging and pooling sample countries' data. Second, the use of VECM and ARDL, which are based on different concepts of cointegration (i.e., Johansen, 
1988; Pesaran et al., 2001), is an invention that helps attach robustness to our analysis (Note 1). Third, most importantly, we extend the finance-growth nexus - the empirical results on this topic have not been reconciled yet - to the finance-growth-crisis nexus. By doing so, more accurate estimates on the finance-growth nexus will be detected as the interaction between finance, growth and crisis must be crucial to determine the effect of finance/growth on each of them. That is, how does financial crisis - as one of endogenous variables in the system - exhibit a background effect on the finance-growth nexus that can be either finance $\rightarrow$ growth or growth $\rightarrow$ finance or finance $\leftrightarrow$ growth (bilateral)? We are also concerned with how both finance and growth influence crisis (finance $\rightarrow$ crisis and growth $\rightarrow$ crisis) having either a positive or negative impact. In particular, assuming that financial boom typically precedes a severe crisis, we predict that the increasing level of financial development has an impact on financial crisis. The remainder is structured as follows. In Section 2, the data used for this article are described. Econometric models and procedures are provided in Section 3. Empirical results are reported in Section 4. And conclusion and policy implications come in the end. We employed the data from the IMF's International Financial Statistics (IFS), the World Bank's Financial Structure Dataset (FSD) and World Development Indicators (WDI), and the publication of the Reserve Bank of India (only for India).

\section{Data}

\subsection{Use of Quarterly Data and Disaggregation of GDP Series}

One important departure of this study is the use of quarterly frequency data (Note 2). Two rationales are given as follows. First, in performing time series analysis, more observations can help obtain statistically acceptable estimates. Especially, as far as developing countries like our sample are concerned, their annual data series cover only a limited span and thus provide fewer observations. Second, as discussed below in Financial Crisis Indicator, the quarterly volatility in each elementary variable is calculated to produce the financial crisis indicator (FC). We argue that quarterly frequency is the best time size to measure volatility and take it into estimation. If monthly volatility is used, it is constantly fluctuating. Besides if annual volatility is computed, it is less fluctuating or actually is a pulse dummy highlighting a crisis year only.

In line with the use of quarterly frequency data, the five countries' annual nominal- and real per capita GDP (nominal GDP deflated by the GDP deflator and the population) series are disaggregated to quarterly ones through the method developed by Chow and Lin (1971) as the quarterly GDP series fully covering the planned period 1982Q1 to 2007Q4 were not available through all the countries. Nominal GDP series are used as a deflator in calculating several elementary variables of financial development and financial repression, and the volatility in nominal GDP is measured as one of the elementary variables of financial crisis (see Appendixes 1, 2 and 4). Likewise, we compute quarterly real per capita GDP and take its logarithm as the economic growth indicator (EG). The five countries' nominal GDP and EG series are plotted in Appendixes 5 to 9. As illustrated, India's EG shows prominent fluctuations around the crisis year 1991, whereas those of four countries show a clear change around the period 1997 to 1998. 


\subsection{Summary Indicators}

In subsequent discussion, we elucidate three summary indicators of the financial development indicator (FD), financial crisis indicator (FC) and financial repression indicator (FR), respectively, which are produced through the principal component approach. The use of the principal component approach to making summary indicators was pioneered by Demetriades and Luintel (1997) and followed by Ang and McKibbin (2007). For conserving space, all information relevant to creating summary indicators is not presented but is given on request. The plots of five countries' summary indicators are provided in Appendixes 5 to 9.

\subsubsection{Financial Development Indicator}

One issue in the empirical literature is that there is no single indicator that sufficiently captures all aspects of financial deepening. As a result, most studies - including pioneering works of King and Levine (1993) and Demetriades and Hussein (1996) and recent ones separately examine the relationship between economic growth (mostly real per capita GDP) and each of several financial development variables (e.g., liquidity liabilities (M3) and domestic credit provided to the private sector). Another issue is that banking and stock market - two major constituents of financial development - have been independently assessed in the literature. Such studies as Levine and Zervos (1998) and Arestis et al. (2001) investigated the effect of stock market development on economic growth. Meanwhile, there are few studies that consider financial development as an integrated phenomenon consisting of banking and stock market, despite the increasing proportion of the latter in a financial system. Taking into account these issues, we argue that financial development - as a single phenomenon - should be measured by combining several elements. And five elementary variables of financial development, which are commonly used in the empirical literature, are selected and integrated to make the financial development indicator (FD) (see Appendix 1) (Note 4). The ratio of money supply to GDP (MTG) is picked up to measure the degree of financial depth in the simplest manner. We are also concerned with the financial size- and activity (liquidity) proxies (BATG, PCTG, SKTG and SVTG) suggested by Beck et al. (1999). With these proxies, the impacts of two financial channels (banking and stock market) and their two aspects (size and activity) are approximated.

\subsubsection{Financial Crisis Indicator}

In creating the financial crisis indicator (FC), we provide the following two points. First, financial crisis should be measured by a rich set of macroeconomic indicators. The rationale is that although financial crises are generally classified into currency- and banking crises, we consider financial crisis as a combined macroeconomic phenomenon consisting of both currency and banking crises (Kaminsky and Reinhart, 1999); in fact, each type of crisis is influenced by several macroeconomic factors (Note 5). Second, obtaining a hint from the ongoing debate in the macroeconomic volatility literature, we consider that while financial fragility - as a continuous phenomenon - can be measured as changing volatility in an economy, financial crisis is identified as an "extreme" volatility in that process (Note 6) (Note 7). Based on these arguments, we calculate the volatility in each of 16 elementary variables of financial crisis (see Appendix 2) by the squared returns. In case of real exchange 


\section{Macrothink}

rate (ER), for example, its volatility is computed as follows:

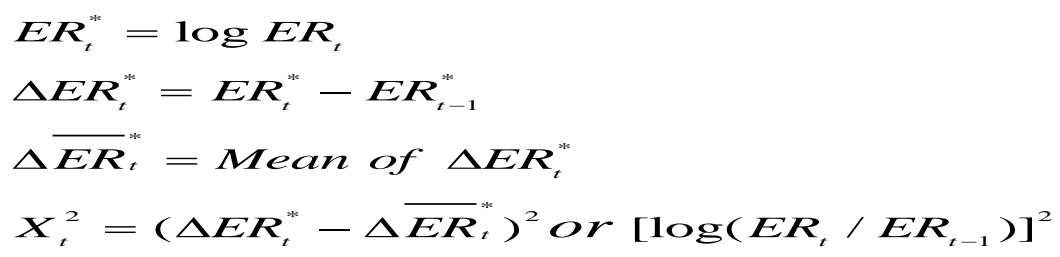

Then we compute a 4-quarter rolling average of $X_{t}^{2}$ as the volatility values in level are too uneven to find more correlations among financial crisis variables for making FC. Since the availability of financial crisis variables and the results of the principal component analysis differ for each of the sample countries, we have created the FCs that consist of different numbers and combinations of financial crisis variables (see Appendix 3). Finally, as described in Appendixes 5 to 9, the plots of the five countries' FCs exhibit the peak or extreme volatility over the crisis periods (i.e., the period 1990 to 1991 for India and the period 1997 to 1998 for the other four countries).

\subsubsection{Financial Repression Indicator}

Financial repression takes the form of such financial distortions as interest rates controls (ceilings), reserve requirements and directed credit. McKinnon (1993, pp.11) defines financial repression as:

"When governments tax (through reserve requirements) and otherwise distort their domestic capital markets (through interest controls and directed credit), the economy is said to be financially repressed".

Another argument is that a high degree of financial repression is associated with high inflation or seigniorage (Bencivenga and Smith, 1992). Moreover we assume that, as the volume of credit provided to the government increases crowding out the credit provided to the private sector, the extent of financial repression is intensified. Based on these arguments, we select eight elementary variables of financial repression (see Appendix 4).

\section{Methodology}

\subsection{Granger Causality}

The basic models of this study are given as follows:

$$
\begin{aligned}
& E G_{i}=f\left(F D_{i}, F C_{i}, F R_{i}\right) \\
& F D_{i}=f\left(E G_{i}, F C_{i}, F R_{i}\right) \\
& F C_{i}=f\left(E G_{i}, F D_{i}, F R_{i}\right)
\end{aligned}
$$

where $E G$ is the economic growth indicator as measured by the logarithm of real per capita GDP, and $F D, F C$ and $F R$ are the financial development, financial crisis and financial 
repression indicators, respectively. Through Equations 3 and 4 , the topic of the finance-growth nexus is addressed, that is, whether the causation runs finance $\rightarrow$ growth or growth $\rightarrow$ finance or bilaterally (finance $\leftrightarrow$ growth). We are also concerned with what impacts financial crisis and financial repression exhibit on economic growth and financial development. Another vital issue is represented by Equation 5, through which the causalities between financial crisis and other underlying variables are investigated.

We conduct Granger causality analysis through the methods of vector error correction model (VECM) and autoregressive distributed lag (ARDL). According to Engle and Granger (1987), cointegrated variables in the vector autoregression (VAR) system must have an error correction representation in which an error correction term (ECT) is incorporated into a model. In the context of assessing the finance-growth nexus, while a simple VAR estimation just indicates that one variable Granger causes the other variable without information of causal direction (e.g., whether finance is positive or negative to growth), both VECM and ARDL show a definite direction through the sign of each underlying variable's coefficient in the cointegrating space. Moreover VECM imposes a strict condition that all underlying variables be integrated of order $1(I(1))$, whereas ARDL can be performed even with the mixture of $I(0)$ and $I(1)$ (Pesaran and Pesaran, 2009). Thus these two techniques stand on different fundamentals of cointegration. Importantly, since the structural break literature was initiated by Perron (1989), the accuracy of conventional unit root and Johansen cointegration tests (i.e., the VECM estimation) has been challenged as the presence of structural break can mimic the unit root stationary autoregressive process. Hence, using both VECM and ARDL can attach more robustness to the analysis.

\subsection{Vector Error Correction Models}

As the initial step for the VECM estimation, the existence of unit root in each underlying variable is assessed by both the Augmented Dickey-Fuller (ADF) test (Said and Dickey, 1984) and the Phillips and Perron (PP) test (Phillips and Perron, 1988). After confirming that all underlying are $I(1)$, we perform the Johansen (1988) cointegration test to check whether there is a cointegrating relationship among underlying variables so that the number of cointegrating vectors $(r)$ is determined. Subsequently, we formulate the VECMs as follows:

$$
\begin{aligned}
\Delta E G_{t}= & \alpha_{1} E C T_{t-1}+\sum_{j=1}^{p-1} \theta_{11} \Delta E G_{t-j}+\sum_{j=1}^{p-1} \theta_{12} \Delta F D_{t-j}+\sum_{j=1}^{p-1} \theta_{13} \Delta F C_{t-j}+\sum_{j=1}^{p-1} \theta_{14} \Delta F R_{t-j} \\
& +\theta_{15} S G D_{t}+\theta_{16} P C D_{t}+\theta_{17} S B G D_{t}+i n p t+u_{1 t} \\
\Delta F D_{t}= & \alpha_{2} E C T_{t-1}+\sum_{j=1}^{p-1} \theta_{21} \Delta E G_{t-j}+\sum_{j=1}^{p-1} \theta_{22} \Delta F D_{t-j}+\sum_{j=1}^{p-1} \theta_{23} \Delta F C_{t-j}+\sum_{j=1}^{p-1} \theta_{24} \Delta F R_{t-j} \\
& +\theta_{25} S G D_{t}+\theta_{26} P C D_{t}+\theta_{27} S B G D_{t}+i n p t+u_{2 t} \\
\Delta F C_{t}= & \alpha_{3} E C T_{t-1}+\sum_{j=1}^{p-1} \theta_{31} \Delta E G_{t-j}+\sum_{j=1}^{p-1} \theta_{32} \Delta F D_{t-j}+\sum_{j=1}^{p-1} \theta_{33} \Delta F C_{t-j}+\sum_{j=1}^{p-1} \theta_{34} \Delta F R_{t-j} \\
& +\theta_{35} S G D_{t}+\theta_{36} P C D_{t}+\theta_{37} S B G D_{t}+i n p t+u_{3 t}
\end{aligned}
$$

where $\Delta$ denotes to the first difference operator, and ECT is the error-correction term - in Equation 6, for example, $E C T=\beta_{11} E G_{t-1}+\beta_{12} F D_{t-1}+\beta_{13} F C_{t-1}+\beta_{14} F R_{t-1}$ in which $\beta_{i j}$ 's are the 
elements of the cointegrating vector - whose coefficient $(\alpha)$ is expected to have a negative sign (Note 8). For avoiding autocorrelation in estimation, we properly allocate: SGD (the shock in economic growth dummy) which takes the value of one for negative EG growth periods otherwise zero; SFD (the shock in financial development dummy) which is one for negative FD growth periods, otherwise zero; and SFCD (the shock in financial crisis dummy) which takes the value of one for positive FC growth periods otherwise zero. Moreover, PCD is the pre-crisis dummy that takes the value of one for 1990Q1 to 1990Q4 and zero for other periods in India's analysis. For the other four countries, PCD is not included. Finally, the allocation of SBGD (the structural break in economic growth dummy) is discussed below in Bai and Perron test.

For giving interference, two types of the causality test are conducted. The first test is the weak exogeneity test in which the null of $H_{0}: \alpha_{j}=0$. Indeed, the weak exogeneity test calculates the significance of the ECT coefficient and thus presents the evidence of long-run causality. The second test is the strong exogeneity test that imposes the strongest restriction of $H_{0}$ : all $\theta_{i j}$ 's $=\alpha_{j}=0$ in each VECM. Although not distinguishing between the short-run- and long-run causalities, the strong exogeneity test indicates the overall causality in the system (Charemza and Deadman, 1997). More weight is put on the strong exogeneity test results, and the two tests are based on chi-square statistics from the Wald test.

\subsection{Autoregressive Distributed Lag Models}

The cointegration test of Johansen (1988) is based on a restrictive assumption that all the underlying variables are integrated of order one or $I(1)$. This assumption is crucial since a mixture of $I(0)$ and $I(1)$ regressors makes standard statistical inference invalid. On the other hand, the ARDL estimation suggested by Pesaran et al. (2001) can be applied even if underlying variables have different orders of integration. The ADRL frameworks for EG, FD and FC as the dependent variables are presented by the following error correction models:

$$
\begin{aligned}
\Delta E G_{t}= & \alpha_{4} E C T_{t-1}+\sum_{j=1}^{p-1} \theta_{41} \Delta E G_{t-j}+\sum_{j=1}^{p-1} \theta_{42} \Delta F D_{t-j}+\sum_{j=1}^{p-1} \theta_{43} \Delta F C_{t-j}+\sum_{j=1}^{p-1} \theta_{44} \Delta F R_{t-j} \\
& +\theta_{45} \Delta S G D_{t}+\theta_{46} \Delta P C D_{t}+\theta_{47} \Delta S B G D_{t}+i n p t+u_{4 t} \\
\Delta F D_{t}= & \alpha_{5} E C T_{t-1}+\sum_{j=1}^{p-1} \theta_{51} \Delta E G_{t-j}+\sum_{j=1}^{p-1} \theta_{52} \Delta F D_{t-j}+\sum_{j=1}^{p-1} \theta_{53} \Delta F C_{t-j}+\sum_{j=1}^{p-1} \theta_{54} \Delta F R_{t-j} \\
& +\theta_{55} \Delta S G D_{t}+\theta_{56} \Delta P C D_{t}+\theta_{57} \Delta S B G D_{t}+i n p t+u_{5 t} \\
\Delta F C_{t}= & \alpha_{6} E C T_{t-1}+\sum_{j=1}^{p-1} \theta_{61} \Delta E G_{t-j}+\sum_{j=1}^{p-1} \theta_{62} \Delta F D_{t-j}+\sum_{j=1}^{p-1} \theta_{63} \Delta F C_{t-j}+\sum_{j=1}^{p-1} \theta_{64} \Delta F R_{t-j} \\
& +\theta_{65} \Delta S G D_{t}+\theta_{66} \Delta P C D_{t}+\theta_{67} \Delta S B G D_{t}+i n p t+u_{6 t}
\end{aligned}
$$

The ECT in Equation 9, for example, takes the form of: $E C T=\beta_{41} E G_{t}+\beta_{42} F D_{t}+\beta_{43} F C_{t}+$ $\beta_{44} F R_{t}+\beta_{45} S G D_{t}+\beta_{46} P C D_{t}+\beta_{47} S B G D_{t}+$ inpt. The ARDL estimation provides $(p+1)^{k}$ number of regressions where $p$ is the maximum number of lags to be used and $k$ is the number of variables in the ARDL equation. At the first stage, we need to conduct the bounds test - the counterpart of the Johansen cointegration test - that computes $F$-statistics to confirm the existence of long-run cointegrating relationships between the underlying 
variables irrespective of whether those variables are $I(0)$ or $I(1)$ (Pesaran and Pesaran, 2009). At the second stage, the optimal lag order for each variable is set. We look for the optimal lags by referring either to the Akaike information criteria (AIC) or to the Schwartz-Bayesian criteria (SBC). Finally, both the weak- and strong exogeneity tests, which are suggested in the VECM analysis, are carried out for each ARDL model.

\subsection{Bai and Perron Test}

It has been generally agreed that a structural break exists in time series data (Note 9). In fact, visually checking the EG (real per capita GDP) plots in Appendixes 5 to 9, India seems to have a break around 1991, whereas the other four countries have prominent breaks over the period 1997-1998. We therefore consider it important to take the element of structural break into our analysis for obtaining more plausible estimates. To this end, the structural break in economic growth dummy (SBGD) is allocated by seeking structural break(s) in each country's EG series through the test developed by Bai and Perron $(1998 ; 2003)$ (hereafter the BP test) (Note 10).

The BP test specifies multiple structural changes in a linear regression model estimated by least squares, treating the dates of structural breaks as unknown and endogenous events. The rationale for performing the BP test is that it allows us to determine break points statistically and objectively not setting the break dates based on a priori information. We conduct the BP test through the following unrestricted vector autoregression model (EG-VAR) where EG is the dependent variable:

$$
\begin{aligned}
E G_{t}= & \sum_{j=1}^{p} \gamma_{1} E G_{t-j}+\sum_{j=1}^{p} \gamma_{2} F D_{t-j}+\sum_{j=1}^{p} \gamma_{3} F C_{t-j}+\sum_{j=1}^{p} \gamma_{4} F R_{t-j} \\
& +\gamma_{5} \text { SGD }_{t}+\gamma_{6} P C D_{t}+i n p t+u_{t}
\end{aligned}
$$

To eliminate autocorrelation in estimation, each EG-VAR has already been included: SGD and PCD for India; SGD and SFD for Indonesia; SFD and SFCD for Korea; SGD and SFCD for Malaysia; and SGD, SFD and SFCD for Thailand (Note 11). As reported in Table 2, the sample periods differ across the five countries due to data availability. Subsequently, we check the lag order selection statistics of each EG-VAR and set three lags for Korea, Malaysia and Thailand and four lags for India and Indonesia (Note 12).

Based on the break dates reported in Table 1, different SBGDs are created. Referring to Thailand's two-break result, for instance, we produced SBGD as illustrated in Figure 1. Thus actually allocating each of those SBGDs - as the deterministic component outside the cointegrating vector - into each country's VECM and ARDL estimations, we have detected that for both India and Indonesia, the one break result is the best (1990Q1 for India and 1997Q4 for Indonesia), whereas for Thailand, the two-break result (1997Q2 and 2003Q1). Here, the selection mainly depends on whether the SBGD allocation provides a single cointegration $(r=1)$ and/or no autocorrelation in estimation. However, SBGDs are not essential for both Korea and Malaysia. In Korea's case, instead of the BP test, we have performed the Zivot and Andrew (1992) (hereafter ZA) test and detected a single structural break in 1997Q4 (Note 13). Based on this single break result, we allocate a zero-one dummy, 


\section{Macrothink}

Research in Applied Economics

ISSN 1948-5433

2012, Vol. 4, No. 2

which is named the ZA dummy (ZAD), in Korea's estimation. On the other hand, in Malaysia's case, any dummy allocations, which are specified either by the BP test or by the ZA test, do not provide better estimates, so that no SBGD is contained in Malaysia's analysis. Finally, Table 2 shows the combinations of dummy variables that are included in the five countries' assessments.

Table 1: Bai and Perron test results

\begin{tabular}{|c|c|c|c|c|}
\hline \multirow[t]{2}{*}{ Country } & \multicolumn{4}{|c|}{ Number of Break(s) } \\
\hline & 1 & 2 & 3 & 4 \\
\hline \multirow[t]{2}{*}{ India } & 1990Q3 & 1990Q3 & 1998Q3; 1994Q2 & - \\
\hline & & 1997Q1 & 1999Q3 & \\
\hline \multirow[t]{2}{*}{ Indonesia } & 1997Q4 & 1997Q1 & 1987Q1; 1997Q1 & - \\
\hline & & 2002Q2 & 2002Q1 & \\
\hline \multirow[t]{2}{*}{ Korea } & 1998Q3 & 1996Q4 & 1988Q3; 1996Q4 & 1987Q4; 1992Q4 \\
\hline & & 2001Q4 & 2001Q4 & 1997Q4; 2002Q4 \\
\hline \multirow[t]{2}{*}{ Malaysia } & 1997Q1 & 1993Q2 & 1988Q1; 1995Q1 & - \\
\hline & & 2000Q2 & 2000Q2 & \\
\hline \multirow[t]{2}{*}{ Thailand } & 1997Q3 & 1997Q2 & 1994Q1; 1998Q3 & - \\
\hline & & 2003Q1 & 2003Q1 & \\
\hline
\end{tabular}

Table 2: Sample periods and dummy variables included

\begin{tabular}{lll}
\hline Country & Sample period & Dummy variables \\
\hline India & 1982Q1 to 2007Q4 & SGD; SBGD (one break); PCD \\
Indonesia & 1982Q1 to 2007Q4 & SGD; SFD; SBGD(one break) \\
Korea & 1983Q1 to 2007Q4 & SFD; SFCD; ZAD \\
Malaysia & 1982Q1 to 2007Q4 & SGD; SFCD \\
Thailand & 1986Q1 to 2007Q4 & SGD; SFD; SFCD; SBGD (two breaks) \\
\hline
\end{tabular}

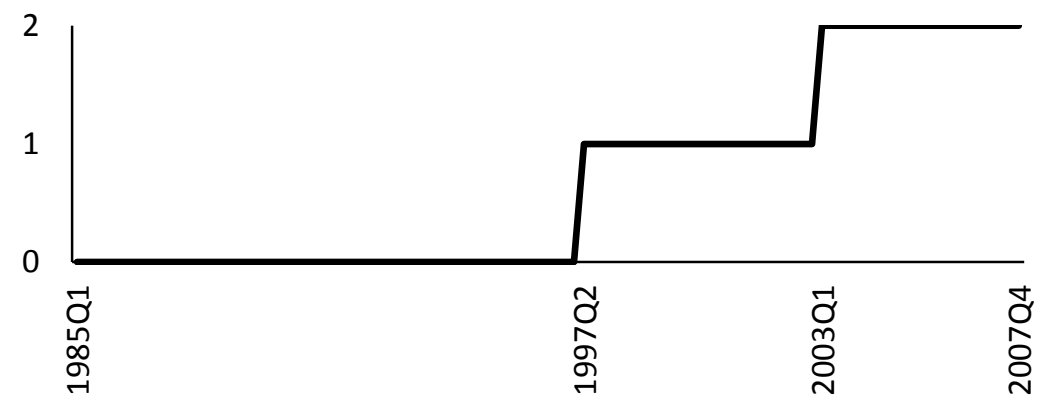

Figure 1: Thailand's SBGD (two breaks)

\section{Empirical Results}

24 models are estimated for the five Asian countries whose sample periods are the same as those in the BP test (see Table 2). While some models indicate the evidence of heteroscedasticity, non-normality and functional form problem, all the models are free from 
autocorrelation at the $10 \%$ significance level or better. If heteroscedasticity is detected, the results are computed by the White heteroscedasticity adjusted standard error (Note 14).

\subsection{Unit root and Cointegration Tests}

For examining stationarity in each series, both the ADF- and PP tests identify that all the countries' EG, FD, FC and FR are non-stationary in their levels (except a few results) but become stationary after taking the first difference. Thus all the underlying variables are confirmed as $I(1)$. Subsequently, the Johansen (1988) cointegration test (with unrestricted intercepts and no trends) is conducted treating FR as an exogenous I(1) variable in the cointegrating vector (Note 15). Before conducting the cointegration test, the lag order of each country's estimation is selected as the Johansen test highly depends on the choice of lag length. Checking the test statistics at the maximum order of four, we choose three lags for Korea, Malaysia and Thailand and four lags for India and Indonesia, respectively. Then the trace statistics in Table 3 report that, there is a single cointegration relationship $(r=1)$ among EG, FD and FC at the $10 \%$ level or better in all countries.

Table 3: Johansen cointegration test results (trace statistics)

\begin{tabular}{lllllll}
\hline Null & Alternative & India & Indonesia & Korea & Malaysia & Thailand \\
\hline$r=0$ & $r=1$ & $47.57^{*}$ & $61.36^{*}$ & $59.20^{*}$ & $37.86^{* *}$ & $56.72^{*}$ \\
$r<=1$ & $r=2$ & 17.12 & 20.12 & 16.21 & 12.5 & 13.8 \\
$r<=2$ & $r=3$ & 2.92 & 0.93 & 0.97 & 2.48 & 4.43 \\
\hline
\end{tabular}

Notes: * and $* *$ denote statistical significance at the 5 and $10 \%$ levels, respectively.

Table 4: Bounds test results and selected orders

\begin{tabular}{|c|c|c|c|}
\hline \multirow[t]{2}{*}{ Country } & \multicolumn{3}{|l|}{ Dependent variable } \\
\hline & $E G$ & FD & $\mathrm{FC}$ \\
\hline India & 0.899 & $3.526 ;(2,4,2,2)$ & $3.225 ;(4,1,4,0)$ \\
\hline Indonesia & 2.395 & 1.451 & $5.362 ;(4,2,2,0)$ \\
\hline Korea & $5.427 ;(1,3,1,0)$ & $2.880 ;(3,1,0,0)$ & $6.323 ;(2,0,0,0)$ \\
\hline Malaysia & 2.552 & $3.936 ;(1,0,0,3)$ & $2.836 ;(3,0,0,0)$ \\
\hline Thailand & 0.627 & 1.180 & $8.342 ;(3,3,1,3)$ \\
\hline
\end{tabular}

Notes: $5 \%$ bounds 3.23 to 4.35 and $10 \%$ bounds 2.72 to 3.77 . In parentheses, the sequence is (EG, FD, FC, FR) for EG model, (FD, EG, FC, FR) for FD model and (FC, EG, FD, FR) for FC model. The sequence is given to the results statistical significant at the $10 \%$ level or better.

\subsection{ARDL procedures}

The bounds test is implemented at the maximum lag order of either four (for India and Indonesia) or three (for Korea, Malaysia and Thailand); we refer to the statistics of the lag order selection in the VECM assessment. The test statistics in Table 4 reveal that, there is cointegration relationship in: all EG, FD and FC for Korea; FD and FC for India and Malaysia; and only FC for Indonesia and Thailand (Note 16). Indeed, although several $F$-statistics in Table 4 are judged as inconclusive in the bounds test, the presence of cointegration has been detected through the conventional unit root tests (i.e., the ADF and PP 
tests) (Note 17). Next while we seek the lag length of each underlying variable, both AIC and SBC give us only the lag selections that seem to cause autocorrelation in both India and Indonesia's models. Hence, the orders of the two countries are manually set as presented in Table 4. For the other three countries, Korea's models are selected by SBC and Malaysia and Thailand's models by AIC, respectively.

\subsection{Finance-Growth Nexus}

In Table 5 the findings relevant to the five Asian countries' finance-growth nexus are reported. "Yes" is based on the strong exogeneity statistics significant at the $10 \%$ level or better, whereas "No" is insignificant strong exogeneity or indicates that cointegration is not detected by the bounds test (see Table 4). The weak exogeneity test results significant at the $10 \%$ level or better are given by " $§$ ". Irrespective of the significance level, financial development and economic growth are positively related to each other in all the countries.

First of all, for India and Malaysia, their finance-growth causality is detected as bilateral in the VECM assessment, whereas their ARDL estimates reject the cointegrating relationship in EG-ARDL (where EG is the dependent variable) and thus suggest the causal link of growth $\rightarrow$ finance. Recognizing these results, we conclude that the finance-growth nexus is primarily bidirectional but more inclining towards growth $\rightarrow$ finance in India and Malaysia. As far as Korea's finance-growth nexus is concerned, while the VECM results support the causal link of growth $\rightarrow$ finance, the ARDL results demonstrate the bilateral causality. However, since the weak exogeneity test results are insignificant in Korea's EG-ARDL and FD-ARDL (where FD is the dependent variable), we highlight the stronger evidence of finance $\rightarrow$ growth in Korea's VECM outcomes. And as far as Indonesia and Thailand are concerned, their finance-growth nexus cannot be investigated through ARDL, as the bounds test results reject the long-run causality between finance and growth in the two countries. Nonetheless the VECM estimates clearly show that the causality runs finance $\rightarrow$ growth in Indonesia and growth $\rightarrow$ finance in Thailand, respectively. Subsequently, the conclusions of the five countries' finance-growth nexus are summarized in Table 6. As we can see, a variation across countries is observed even though the same variables and methodology are employed for all the countries. The demand-leading hypothesis - economic growth leads to higher financial development but not vice versa - is supported by Thailand's results. Although their finance-growth nexus is concluded as bilateral, both India and Malaysia's estimates partially support the demand-leading hypothesis. On the other hand, the supply-leading hypothesis (finance $\rightarrow$ growth) is endorsed by Indonesia and Korea.

Table 5: Finance-growth-crisis nexus (1)

\begin{tabular}{|c|c|c|c|c|}
\hline \multirow[t]{2}{*}{ Country } & \multicolumn{2}{|c|}{ Finance $\rightarrow$ growth } & \multicolumn{2}{|c|}{ Growth $\rightarrow$ finance } \\
\hline & EG-VECM & EG-ARDL & FD-VECM & FD-ARDL \\
\hline India & Yes $^{* *}$ & No & Yes $^{\star \S}$ & Yes $^{* \S}$ \\
\hline Indonesia & Yes ${ }^{\star \star \S}$ & No & No & No \\
\hline Korea & $Y_{e s}{ }^{\star \S}$ & Yes* & No & Yes $^{*}$ \\
\hline Malaysia & $\mathrm{Yes}^{* \star \S}$ & No & Yes $^{* \S}$ & Yes $^{* \S}$ \\
\hline Thailand & No & No & Yes ${ }^{\star \star \star \S}$ & No \\
\hline
\end{tabular}




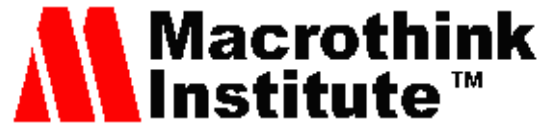

Notes: $* * *$ and $* * *$ denote statistical significance at the 1, 5 and $10 \%$ levels, respectively. $\S$ shows that the weak exogeneity test result is significant at the $10 \%$ level or better. In all the countries, both finance and growth positively relate to each other.

Table 6: Finance-growth-crisis nexus (2)

\begin{tabular}{ll}
\hline Country & Result \\
\hline India & Finance $\leftrightarrow$ growth but more inclining toward growth $\rightarrow$ finance \\
Indonesia & Finance $\rightarrow$ growth \\
Korea & Finance $\rightarrow$ growth \\
Malaysia & Finance $\leftrightarrow$ growth but more inclining toward growth $\rightarrow$ finance \\
Thailand & Growth $\rightarrow$ finance \\
\hline
\end{tabular}

\subsection{Finance-Growth-Crisis Nexus}

Table 7 documents the effects of financial crisis either on growth or on finance. The results are summarized as: (1) crisis $\rightarrow$ finance $(+)$ in India; (2) no significant finding for Indonesia; (3) different estimates are detected through VECM and ARDL in Korea; (4) crisis $\rightarrow$ finance $(+)$ and crisis $\rightarrow$ growth $(-)$ in Malaysia; and (5) crisis $\rightarrow$ finance $(+)$ in Thailand. Likewise Table 8 reports how financial crisis is caused by financial development, economic growth and financial repression. We identify growth $\rightarrow$ crisis(-) and finance $\rightarrow$ crisis $(+)$ in all the countries except Korea where growth $\rightarrow$ crisis $(+)$ and finance $\rightarrow$ crisis(-). As far as the impact of repression on crisis is concerned, it is repression $\rightarrow$ crisis $(+)$ in all the countries except Thailand where repression $\rightarrow$ crisis(-).

Table 7: Finance-growth-crisis nexus (1)

\begin{tabular}{|c|c|c|c|c|}
\hline \multirow[t]{2}{*}{ Country } & \multicolumn{2}{|c|}{$\underline{\text { Crisis } \rightarrow \text { growth }}$} & \multicolumn{2}{|c|}{$\underline{\text { Crisis } \rightarrow \text { finance }}$} \\
\hline & EG-VECM & EG-ARDL & FD-VECM & FD-ARDL \\
\hline India & No & No & $\operatorname{Yes}(+)^{*}$ & $\mathrm{No}^{\S}$ \\
\hline Indonesia & $\mathrm{No}^{\S}$ & No & No & No \\
\hline Korea & Yes $(+)^{\star \S}$ & No & No & Yes $(+)^{*}$ \\
\hline Malaysia & Yes $(-)^{\star \S}$ & No & $\operatorname{Yes}(+)^{* \S}$ & $\operatorname{Yes}(+)^{*}$ \\
\hline Thailand & No & No & $\operatorname{Yes}(+)^{* \star \star \S}$ & No \\
\hline
\end{tabular}

Notes: $*$ and $* * *$ denote statistical significance at the 1 and $10 \%$ levels, respectively. $§$ shows that the weak exogeneity test result is significant at the $10 \%$ level or better. (+) and (-) indicate positive and negative links (the causal direction of financial repression is confirmed by its sign in the cointegrating vector).

Table 8: Finance-growth-crisis nexus (2)

\begin{tabular}{|c|c|c|c|c|c|c|}
\hline \multirow[t]{2}{*}{ Country } & \multicolumn{2}{|c|}{ Growth $\rightarrow$ crisis } & \multicolumn{2}{|c|}{$\underline{\text { Finance } \rightarrow \text { crisis }}$} & \multicolumn{2}{|c|}{$\underline{\text { Repression } \rightarrow \text { crisis }}$} \\
\hline & FC-VECM & FC-ARDL & FC-VECM & FC-ARDL & FC-VECM & FC-ARDL \\
\hline India & Yes $(-)^{*}$ & $\operatorname{Yes}(-)^{*}$ & $\operatorname{Yes}(+)^{*}$ & $\operatorname{Yes}(+)^{*}$ & $\operatorname{Yes}(+)^{*}$ & $\mathrm{Yes}(+)^{*}$ \\
\hline Indonesia & Yes $(-)^{*}$ & $\operatorname{Yes}(-)^{*}$ & $\operatorname{Yes}(+)^{*}$ & $\operatorname{Yes}(+)^{*}$ & $\operatorname{Yes}(+)^{*}$ & Yes $(+)^{*}$ \\
\hline Korea & $\operatorname{Yes}(+)^{*}$ & $\operatorname{Yes}(+)^{*}$ & $\operatorname{Yes}(-)^{*}$ & $\operatorname{Yes}(-)^{*}$ & $\operatorname{Yes}(+)^{*}$ & $\operatorname{Yes}(+)^{*}$ \\
\hline Malaysia & $\mathrm{No}^{\mp}$ & Yes $(-)^{*}$ & $\mathrm{No}^{\mp}$ & $\operatorname{Yes}(+)^{*}$ & $\mathrm{No}^{\mp}$ & $\operatorname{Yes}(+)^{*}$ \\
\hline Thailand & Yes $(-)^{*}$ & Yes $(-)^{*}$ & $\operatorname{Yes}(+)^{*}$ & $\operatorname{Yes}(+)^{*}$ & Yes $(-)^{*}$ & Yes $(-)^{*}$ \\
\hline
\end{tabular}


Notes: * denotes statistical significance at the $1 \%$ level. $\mp$ shows that the weak exogeneity test result of Malaysia's FC-VECM is insignificant, whereas the same results of all the other models are significant at the $10 \%$ level or better. (+) and (-) indicate positive and negative links (the causal direction of financial repression is confirmed by its sign in the cointegrating vector).

Looking at the results in Tables 7 and 8, we highlight a positive bilateral causality of finance $\leftrightarrow$ crisis that is discovered in India, Malaysia and Thailand. This causation might be due to financial boom that can unusually increase the volume of credit and/or encourage stock market activities in an economy irrespective of real sector conditions. Therefore the causality of finance $\leftrightarrow$ crisis $(+)$ implies that if the government or monetary authorities adopt a policy that simply increases volatility in an economy, the extent of financial deepening further rises. However, such volatility-led policy implication is obviously adverse and dangerous, leading to financial fragility and ultimately to financial crisis. This process coincides with our initial prediction that financial boom ends up with financial crisis. Different is Korea where a positive bilateral causality of growth $\leftrightarrow$ crisis is observed and a uniformed result is not found for the causality between finance and crisis. Thus our analysis documents that Korea's transmission mechanisms relevant to financial crisis differs from those in the other countries.

Next the casual link between crisis and repression is discussed. As given in Table 8, it is repression $\rightarrow$ crisis(+) in India, Indonesia, Korea and Malaysia and repression $\rightarrow$ crisis(-) in Thailand. While the high degree of financial repression seems to cause financial crisis in four countries, it is inverted in Thailand where the low degree of financial repression is clearly observed immediately before the Asian crisis (see Appendix 9(e)). For the countries except Thailand, we consider that an extremely high degree of financial repression in a boom period attracted more speculative funds - rather than contained a credit boom - further increasing the volatility in those economies where the financial market was progressively liberalized but not well regulated and controlled. Such a mechanism might have worked in India, Indonesia, Korea and Malaysia before these countries were severely hit by financial crisis. For Thailand, on the other hand, an expansionary financial trend - as approximated by the low degree of FR - might have typically created a financial boom led by investment opportunities that were rapidly increasing but were not properly hedged.

\section{Conclusion}

This article examines the causality between financial development, economic growth and financial crisis in India, Indonesia, Korea, Malaysia and Thailand through the techniques of VECM and ARDL. As far as the results of the finance-growth nexus are concerned, although the same variables and methodology are employed, different causal directions (i.e., either finance $\rightarrow$ growth or growth $\rightarrow$ finance or finance $\leftrightarrow$ growth) have been detected across the five Asian countries. This fact supports the validity of country-by-country analysis employing time series techniques over the cross-country and panel data analysis that seeks a single generalized result by pooling and averaging several countries' data. Besides our findings are more plausible than those from a simple bivariate model since financial crisis, financial repression and structural break - which exhibit vital background effects on the 
finance-growth nexus - are taken into estimation. Moreover, the use of VECM and ARDL adds more robustness to the analysis as the long-run relationship has been confirmed through two different types of cointegration test. One limitation of this study is that it requires the sample countries to offer a variety of long enough, consecutive data series. Therefore, it is not readily applicable to countries like Sub-Saharan African countries whose data scarcity is well known. However, as long as sufficient data series are provided, the analysis can be implemented, through which each country's estimate is compared with others. Finally, we present the following policy implications. First, the positive effect of finance on growth should be evaluated with the fact that deeper financial development can lead to financial crisis. Therefore, while the positive impact of finance $\rightarrow$ growth is confirmed, we must mind the adverse effect due to the positive bilateral causality of finance $\leftrightarrow$ crisis as the substantial cost of financializing an economy. Second, based on the findings of the link between crisis and repression, we argue that, in regulating the financial systems, the roles of governments and monetary authorities are crucial and their prime emphasis should be put on reducing and eliminating the threat of financial crisis whose cost is economically and socially huge.

\section{References}

Ang, J. B., \& McKibbin, W. J. (2007). Financial liberalisation, financial sector development and growth: evidence from Malaysia. Journal of Development Economics, 84 (1), 215-233. http://dx.doi.org/10.1016/j.jdeveco.2006.11.006

Arestis, P., Demetriades, P., Fattouh, B., \& Mouratidis, K. (2002). The impact of financial liberalisation on financial development: evidence from developing economies. International Journal of Finance and Economics, 7 (2), 109-121. http://dx.doi.org/10.1002/ijfe.181

Arestis, P., Demetriades, P., \& Luintel, K. B. (2001). Financial development and economic growth: the role of stock markets. Journal of Money, Credit and Banking, 33 (1), 16-41. http://dx.doi.org/10.2307/2673870

Bai, J., \& Perron, P. (1998). Estimating and testing linear models with multiple structural changes. Econometrica, 66 (1), 47-78. http://dx.doi.org/10.2307/2998540

Bai, J., \& Perron, P. (2003). Computation and analysis of multiple structural change models. Journal of Applied Econometrics, 18 (1), 1-22. http://dx.doi.org/10.1002/jae.659

Beck, T., Demirgüç-Kunt, A., \& Levine, R. (1999). A new database on financial development and structure (Policy Research Working Paper No. 2146). Washington, DC: World Bank. Retrieved from: http://www-wds.worldbank.org/servlet/WDSContentServer/WDSP/IB/1999/09/10/0000 94946_99082405304075/Rendered/PDF/multi_page.pdf

Bencivenga, V., \& Smith, B. D. (1992). Deficits, inflation and the banking system in developing countries: the optimal degree of financial repression. Oxford Economic Papers, 44 (4), 767-790. http://www.jstor.org/stable/2663388 


\section{MInstitute Macrothink}

Boot, J. C. G., Feibes, W., \& Lisman, J. H. C. (1967). Further methods of derivation of quarterly figures from annual data. Applied Statistics, 16 (1), 65-75. http://dx.doi.org/10.2307/2985238

Charemza, W. W., \& Deadman, D. F. (1997). New Directions in Econometric Practice (2nd ed.). Cheltenham: Edward Elgar.

Chow, G., \& Lin, A. (1971). Best linear unbiased interpolation, distribution and extrapolation of time series by related series. Review of Economics and Statistics, 53 (4), 372-375. http://dx.doi.org/10.2307/1928739

Demetriades, P. O., \& Hussein, K. A. (1996). Does financial development cause economic growth?: time-series evidence from 16 countries. Journal of Development Economics, 51 (2), 387-411. http://dx.doi.org/10.1016/S0304-3878(96)00421-X

Demetriades, P. O., \& Luintel, K. B. (1997). The direct costs of financial repression: evidence from India. Review of Economics \& Statistics, 97 (2), 311-320. http://dx.doi.org/10.1162/003465397556665

Engle, R. F., \& Granger, C. W. J. (1987). Co-integration and error correction: representation, estimation and testing. Econometrica, 55 (2), 251-276. http://dx.doi.org/10.2307/1913236

Enisan, A. A., \& Olufisayo, A. O. (2009). Stock market development and economic growth: evidence from seven sub-Sahara African countries. Journal of Economics and Business, 61 (2), 162-171. http://dx.doi.org/10.1016/j.jeconbus.2008.05.001

Johansen, S. (1988). Statistical analysis of cointegration vectors. Journal of Economic

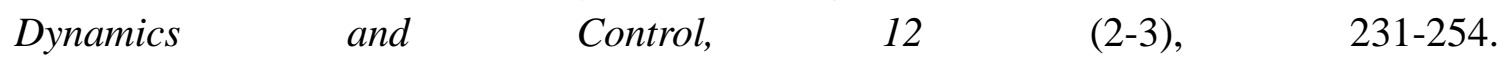
http://dx.doi.org/10.1016/0165-1889(88)90041-3

Kaminsky, G. L., Lizondo, S., \& Reinhart, C. M. (1998). Leading indicators of currency crises. IMF Staff Papers, 45 (1), 1-48. http://dx.doi.org/10.2307/3867328

Kaminsky, G. L., \& Reinhart, C. M. (1999). The twin crises: the causes of banking and balance-of-payments problems. American Economic Review, 89 (3), 473-500. http://dx.doi.org/10.1257/aer.89.3.473

King, R. G., and Levine, R. (1993). Finance and growth: Schumpeter might be right. Quarterly Journal of Economics, 108 (3), 717-737. http://dx.doi.org/10.2307/2118406

Kose, M. A., Prasad, E. S., \& Terrones, M. E. (2006). How do trade and financial integration affect the relationship between growth and volatility? Journal of International Economics, 69 (1), 176- 202. http://dx.doi.org/10.1016/j.jinteco.2005.05.009

Levine, R., and Zervos, S. (1998). Stock markets, banks and economic growth. American Economic Review, 88 (3), 537-558. http://www.jstor.org/pss/116848

Luintel, K. B., and Khan, M. (1999). A quantitative reassessment of the finance-growth nexus: evidence from a multivariate VAR. Journal of Development Economics, 60 (2), 
381-405. http://dx.doi.org/10.1016/S0304-3878(99)00045-0

McKinnon, R. (1973). Money and Capital in Economic Development. Washington, DC: Brookings Institution.

McKinnon, R. (1993). The Order of Economic Liberalisation: Financial Control in the Transition to a Market Economy (2nd ed.). Baltimore and London: Johns Hopkins University Press.

Perron, P. (1989). The great crash, the oil price shock and the unit root hypothesis. Econometrica, 57 (6), 1361-1401. http://dx.doi.org/10.2307/1913712

Perron, P. (2006). Dealing with structural breaks. In K. Patterson and T. C. Mills (Eds.), Palgrave Handbook of Econometrics Volume 1: Econometric Theory (pp. 278-352). London: Palgrave Macmillan.

Perron, P., \& Vogelsang, T. J. (1992). Nonstationarity and level shifts with an application to purchasing power parity. Journal of Business and Economic Statistics, 10 (3), 301-320. http://dx.doi.org/10.2307/1391544

Pesaran, M. H., \& Pesaran, B. (2009). Time Series Econometrics Using Microfit 5.0. Oxford: Oxford University Press.

Pesaran, M. H., Shin, Y., \& Smith, R. J. (2000). Structural analysis of vector error correction models with exogenous I(1) variables. Journal of Econometrics, 97 (2), 293-343. http://dx.doi.org/10.1016/S0304-4076(99)00073-1

Pesaran, M. H., Shin, Y., \& Smith, R. J. (2001). Bounds testing approaches to the analysis of level relationships. Journal of Applied Econometrics, 16 (3), 289-326. http://dx.doi.org/10.1002/jae.616

Phillips, P. C. B., \& Perron, P. (1988). Testing for unit root in time series regression. Biometrika, 75 (2), 335-346. http://dx.doi.org/10.1093/biomet/75.2.335

Ramey, G., \& Ramey, V. A. (1995). Cross-country evidence on the link between volatility and growth. American Economic Review, $85 \quad$ (5), 1138-1151. http://www.jstor.org/pss/2950979

Reserve Bank of India (1985). Report of the Committee to Review the Working of the Monetary System. Mumbai: Reserve Bank of India.

Said, S. E., \& Dickey, D. A. (1984). Testing for unit roots in autoregressive moving average models of unknown order. Biometrika, $71 \quad$ (3), 599-607. http://dx.doi.org/10.1093/biomet/71.3.599

Shaw, E. (1973). Financial Deepening in Economic Development. London: Oxford University Press.

Verma, R., \& Wilson, E. J. (2005). A multivariate analysis of savings, investment and growth in India (Working Paper No. 05-24). Wollongong: Department of Economics, University 
of Wollongong. http://econpapers.repec.org/paper/uowdepec1/wp05-24.htm

World Bank (1993). The East Asian Miracle: Economic Growth and Public Policy. New York: Oxford University Press.

Zivot, E., \& Andrew, D. W. K. (1992). Further evidence on the great crash, the oil-price and the unit root hypothesis. Journal of Business and Economic Statistics, 10 (3), 251-270. http://dx.doi.org/10.2307/1391541

\section{Notes}

Note 1. Using ARDL and VECM techniques, Enisan and Olufisayo (2009) examined the causality between stock market development and economic growth in African countries.

Note 2. It is pointed out that quarterly frequency data are usually associated with short-run cyclical fluctuations of the economy. Hence, if a series exhibits a prominent seasonality, it is removed from that series through proper statistical procedures.

Note 3. The combinations of indicators (industrial production and export volume) are different among the sample countries. We empirically confirmed that each of those combinations is important to avoid autocorrelation in each country's estimation.

Note 4. In this article, a summary "indicator" is made of several elementary variables.

Note 5. For selecting the elementary variables of financial crisis, we reviewed the "leading indicators of crisis" or early warning system (EWS) literature pioneered by Kaminsky et al. (1998).

Note 6 . The macroeconomic volatility literature initially concerns the link between economic growth and volatility (e.g., Ramey and Ramey, 1995) and recently was extended to studying that linkage in terms of globalization, that is, growing international trade and financial integration (e.g., Kose et al., 2006).

Note 7. "Many of these (emerging) economies have experienced rapid growth but have also been subject to high volatility, most prominently in the form of severe financial crises that befell many of them during the last decade and a half" (Kose et al., 2006, pp.177).

Note 8. Since the dummy variables included are different across countries (see Table 2), Equations 6 to 11 are India's VECM and ARDL models.

Note 9. For a comprehensive review of the structural break literature, see Perron (2006).

Note 10. We refer to Verma and Wilson (2005) who detected a structural break in India's annual GDP series around 1989 with the test suggested by Perron and Vogelsang (1992) and allocate zero and one dummies assuming the year 1989 as the break point.

Note 11. Equation 12 is for India's estimation.

Note 12. All the results of the BP test are not reported but are given on request. 


\section{Macrothink}

Research in Applied Economics

ISSN 1948-5433

2012, Vol. 4, No. 2

Note 13. The ZA test is an autoregressive structural break test that specifies a single unknown break as an endogenous event.

Note 14. To conserve space, all the results are not reported but are given on request.

Note 15. For details, see Pesaran et al. (2000).

Note 16. The bonds test was done through Microfit 4.1.

Note 17. For the bounds test procedures, see Pesaran and Pesaran (2009).

\section{Appendix}

Appendix 1. Elementary Variables of Financial Development

\begin{tabular}{|c|c|}
\hline Definition (Name) & Source \\
\hline Money supply / GDP (MTG) & Line 35L (for money supply) and 99B (for GDP) \\
\hline Deposit money bank assets / GDP (BATG) & $\begin{array}{l}\text { All categories of line } 22 \text { (for deposit money bank assets) } \\
\text { and line 99B }\end{array}$ \\
\hline $\begin{array}{l}\text { Private credit by deposit money banks / GDP } \\
\text { (PCTG) }\end{array}$ & Line 32D (for private credit) and 99B \\
\hline Stock market capitalization / GDP (SKTG) & FSD \\
\hline Stock market total value / GDP (SVTG) & FSD \\
\hline
\end{tabular}

Notes: All the "lines" refer to those of the International Financial Statistics (IFS). Annual series of SKTG and SVTG are disaggregated to quarterly ones by the Boot et al. (1967) method. FSD = Financial Structure Dataset. 
Appendix 2. Elementary Variables of Financial Crisis

\begin{tabular}{|c|c|}
\hline Definition (Name) & Source \\
\hline Exchange rate (ER) & $\begin{array}{l}\mathrm{ER}=\mathrm{NER} * \text { (USCPI / SCPI) where NER is nominal exchange rate (line RF), } \\
\text { and USCPI and SCPI are US and sample country's consumer price indexes, } \\
\text { respectively. }\end{array}$ \\
\hline $\begin{array}{l}\text { Money supply / foreign exchange } \\
\text { reserve (MTF) }\end{array}$ & $\begin{array}{l}\text { MTF }=\text { NM } /(\text { FER } * \text { NER) where NM is nominal money supply (line } 35 \mathrm{~L} \text { ), and } \\
\text { FER is foreign exchange reserve (line 1D). }\end{array}$ \\
\hline External debt $(\mathrm{ED})^{\S}$ & $\mathrm{ED}=(\mathrm{NED} * \mathrm{NER}) / \mathrm{CPI}$ where NED is nominal external debt $(\mathrm{WDI})$ \\
\hline Trade volume (TV) & $\mathrm{TV}=[(\mathrm{X}+\mathrm{I}) * \mathrm{NER}] / \mathrm{CPI}$ where $\mathrm{X}+\mathrm{I}$ is exports + imports (lines 70 and 71$)$ \\
\hline Oil price (OP) & $\mathrm{OP}=(\mathrm{NOP} * \mathrm{NER}) / \mathrm{CPI}$ where NOP is nominal oil price (line 76AA) \\
\hline Fiscal deficit $(\mathrm{FCD})^{\S}$ & $\begin{array}{l}\text { FCD = NFCD } / \text { CPI where NFCD is nominal fiscal deficit (Reserve Bank of } \\
\text { India) } \\
\text { (for India). }\end{array}$ \\
\hline $\begin{array}{l}\text { Gov. consumption expenditure } \\
(\text { GCE })^{\S}\end{array}$ & $\begin{array}{l}\text { GCE = NGCE / CPI where NGCE is nominal government consumption } \\
\text { expenditure (line 91) (for Indonesia, Korea, Malaysia and Thailand). }\end{array}$ \\
\hline Share price (SP) & $\mathrm{SP}=\mathrm{NS} / \mathrm{CPI}$ where NSP is nominal share price (line 62 ). \\
\hline Inflation rate (IR) & $\mathrm{IR}=[(\mathrm{CPI}-\mathrm{CPI}(-1)) / \mathrm{CPI}(-1)] * 100$ \\
\hline Real interest rate (RR) & $R R=N R-I R$ where NR is nominal interest rate (discount rate) (line 60). \\
\hline GDP $(\mathrm{GDP})^{\S}$ & GDP = NGDP / CPI where NGDP is nominal GDP (line 98B). \\
\hline Money supply (MS) & $\mathrm{MS}=\mathrm{NM} / \mathrm{CPI}$ \\
\hline Total domestic deposit (TD) & $\begin{array}{l}\text { TD }=\text { NTD / CPI where NTD is the sum of demand- and time deposits (lines } 24 \\
\text { and 25). }\end{array}$ \\
\hline Deposit money bank assets (BA) & $\mathrm{BA}=\mathrm{NBA} / \mathrm{CPI}$ where NBA is nominal bank assets (all categories of line 22). \\
\hline $\begin{array}{l}\text { Private credit by deposit money } \\
\text { banks (PC) }\end{array}$ & $\mathrm{PC}=\mathrm{NPC} / \mathrm{CPI}$ where NPC is nominal private credit (line 32D). \\
\hline $\begin{array}{l}\text { Stock market capitalization / } \\
\text { GDP }(\mathrm{SKTGV})^{\S}\end{array}$ & FSD \\
\hline $\begin{array}{l}\text { Stock market total } \\
\text { value / GDP }(\mathrm{SVTGV})^{\S}\end{array}$ & FSD \\
\hline
\end{tabular}

Notes: All the "lines" refer to those of the International Financial Statistics (IFS). § indicates that annual series are disaggregated to quarterly ones by the Boot et al. (1967) method except GDP that is by the Chow and Lin (1971) method. WDI = World Development Indicators. FSD = Financial Structure Dataset.

Appendix 3. Asian Countries' Selected Elementary Variables of Financial Crisis

\begin{tabular}{ll}
\hline Country & Financial Crisis Variables \\
\hline India & ER; MTF; ED; TV; OP; FCD; SP; IR; GDP; MS; TD; SKTGV \\
Indonesia & ER; MTF; ED; TV; OP;GCE; IR; MS; TD; BA; PC \\
Korea & ER; MTF; TV;SP; IR; GDP; MS; TD; SKTGV; SVTGV \\
Malaysia & ER; ED; TV; GCE; SP; IR; SKTGV \\
Thailand & ER; MTF; ED; TV; GCE; IR; GDP; MS; TD; SKTGV \\
\hline
\end{tabular}


Appendix 4. Elementary Variables of Financial Repression

\begin{tabular}{ll}
\hline Definition (Name) & Source \\
\hline Nominal interest rate (NR) & Line 60 (for bank rate) \\
Com. bank reserve / m. supply (CRTM) & Lines 20 (for CB reserves) and 35L (for m. supply) \\
Com. bank reserve / GDP (CRTG) & Lines 20 and 99B (for GDP) \\
Com. bank reserve / total deposit (CRTD) & Lines 20 and 24 and 25 (for total deposit) \\
Claims on the gov. / m. supply (GTM) & Lines 32AN (for claim on the government) and 35L \\
Claims on the gov. / GDP (GTG) & Lines 32AN and 99B \\
Claims on the gov. / total domestic credit (GTD) & Lines 32AN and 32 (for total domestic credit) \\
Inflation tax (Seigniorage) (IT) & Change in reserve money (line 14) / GDP (line 99B) \\
\hline
\end{tabular}

Notes: All the "lines" refer to those of the International Financial Statistics (IFS).

Appendix 5. India's EG and Summary Indicators

(a) EG

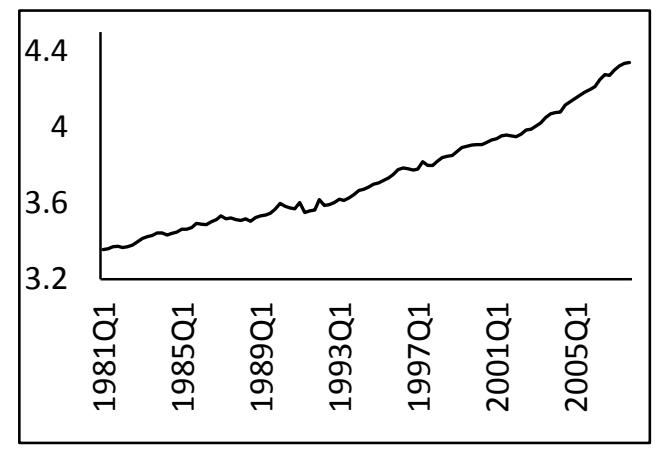

(c) $\mathrm{FC}$

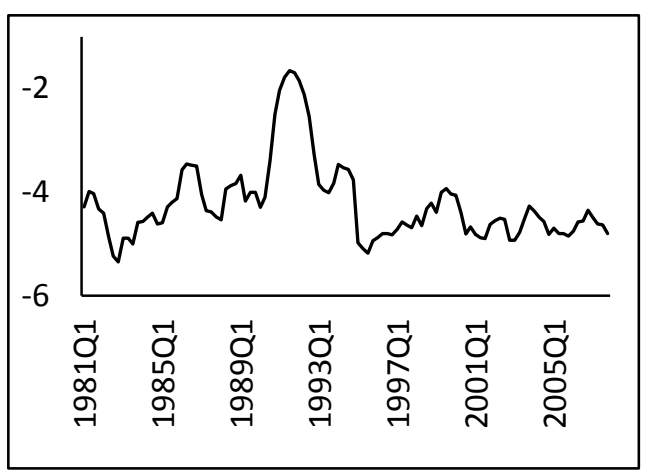

(b) FD

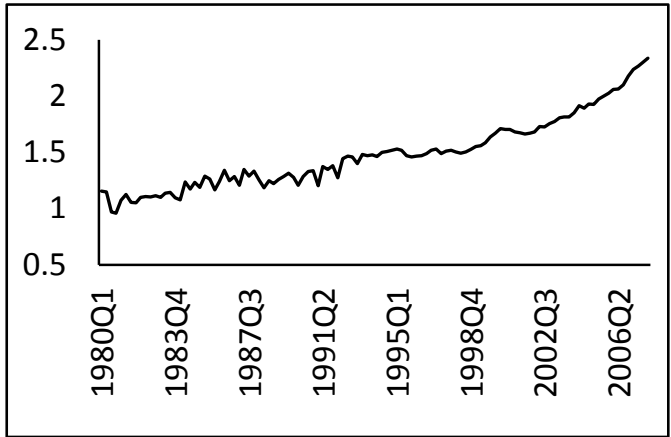

(d) FR

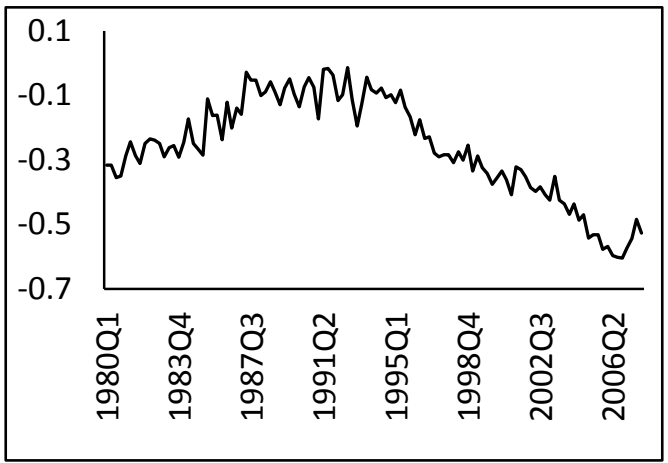

Appendix 6. Indonesia's EG and Summary Indicators

(a) EG

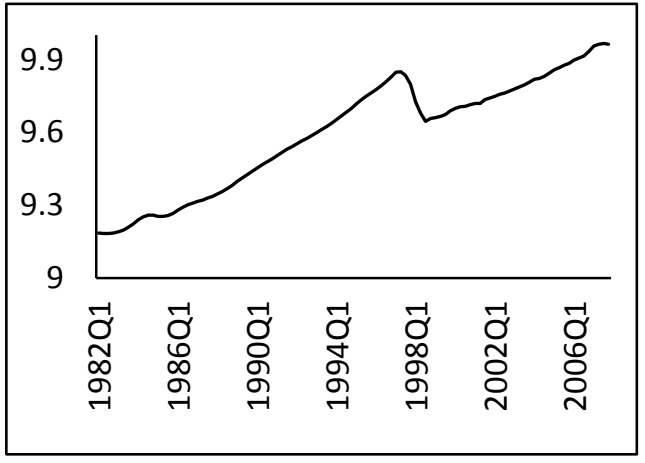

(b) FD

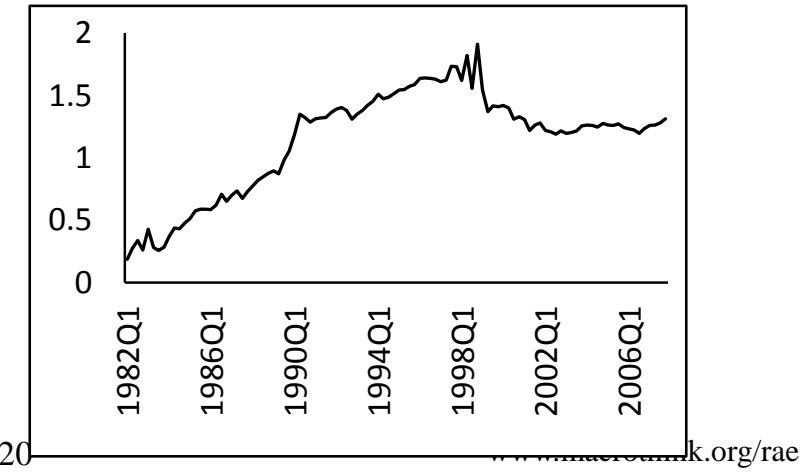


(c) $\mathrm{FC}$

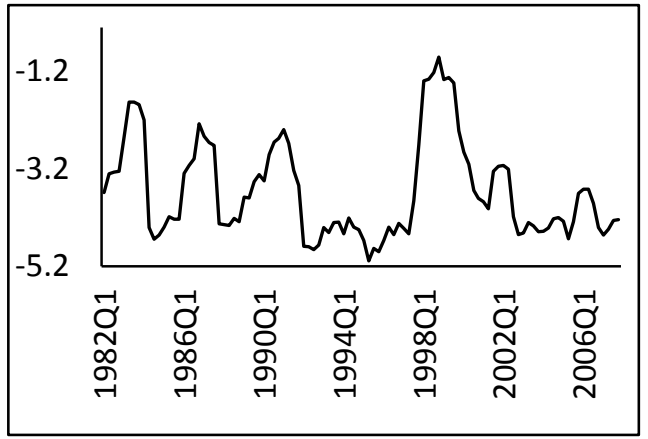

(d) FR

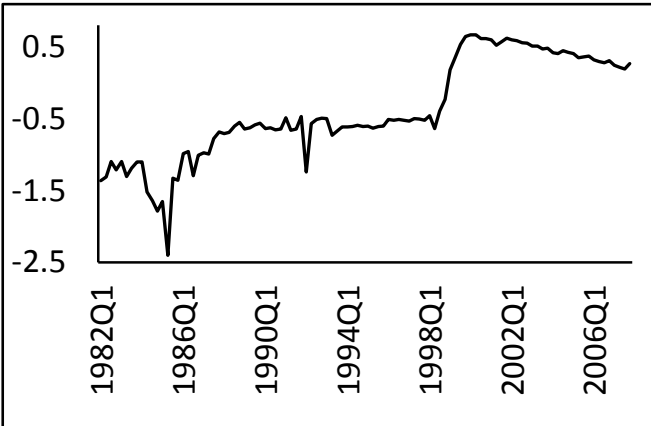

Appendix 7. Korea's EG and Summary Indicators

(a) EG

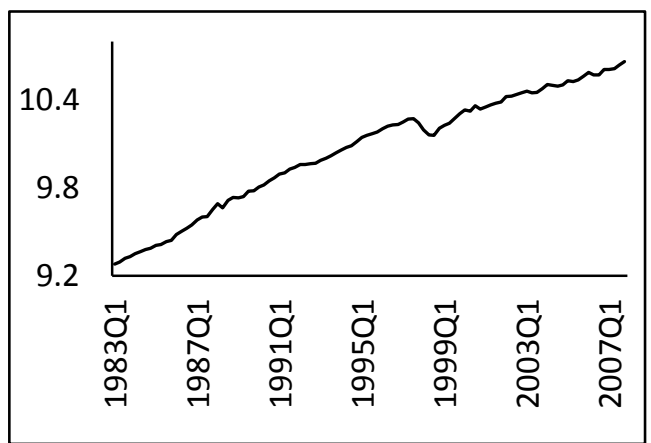

(c) FC

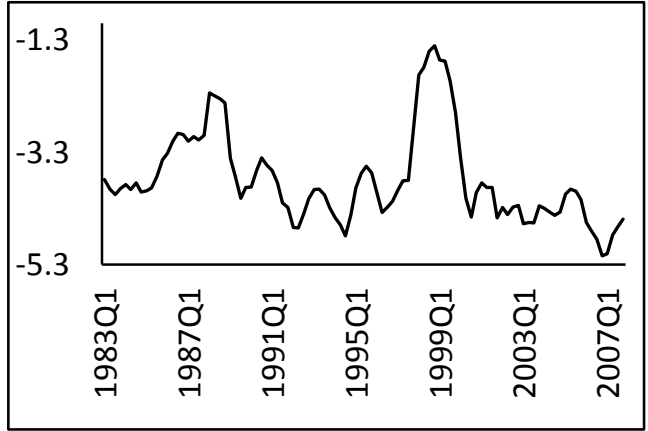

(b) FD

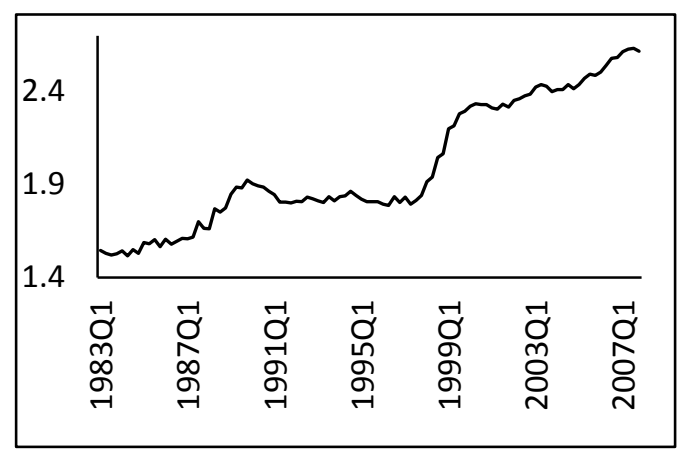

(d) FR

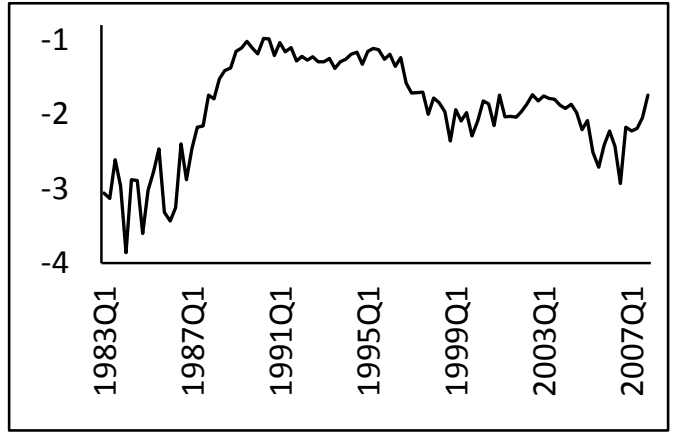

Appendix 8. Malaysia's EG and Summary Indicators

(a) EG

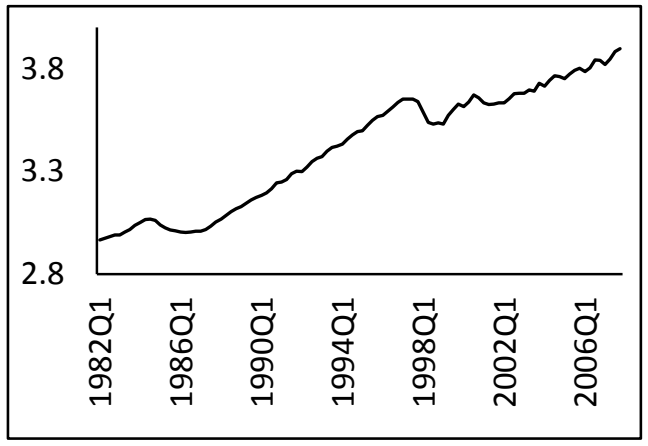

(b) FD

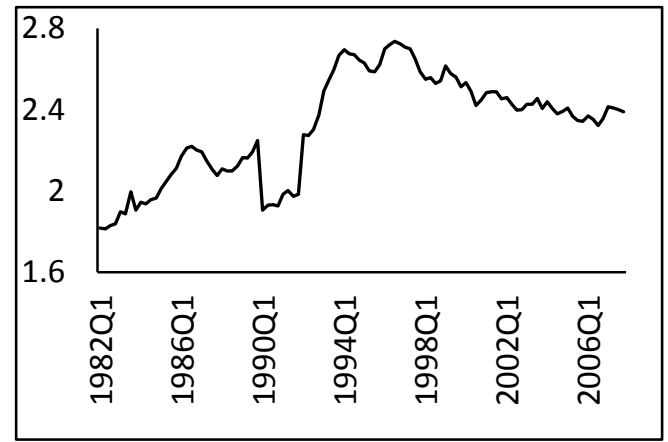


(c) FC

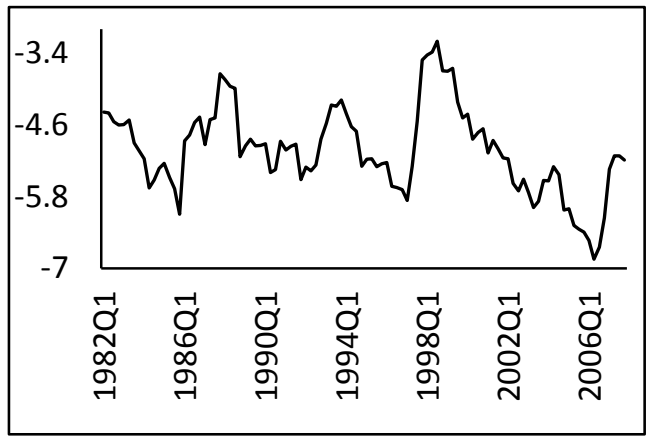

(d) FR

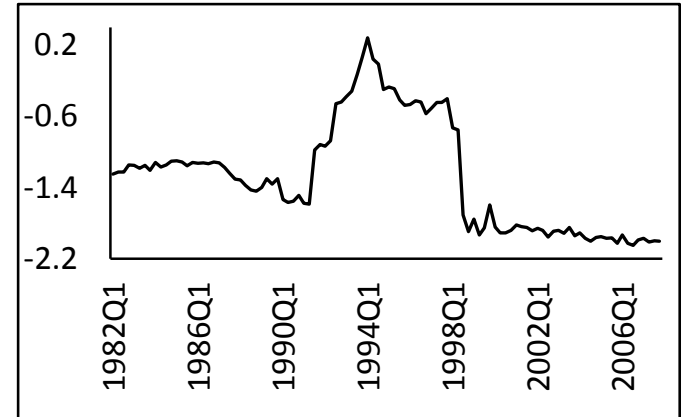

Appendix 9. Thailand's EG and Summary Indicators

(a) EG

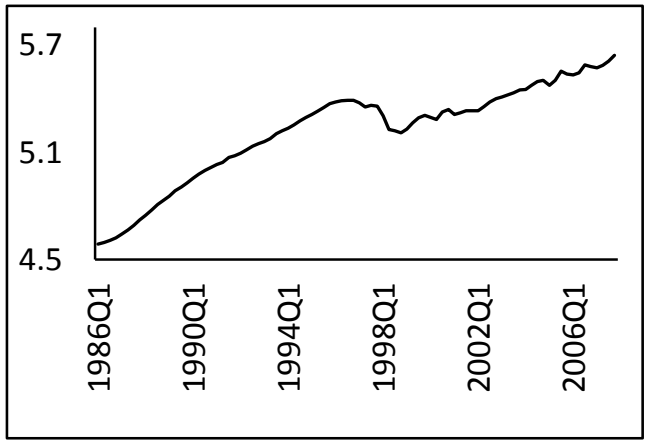

(c) FC

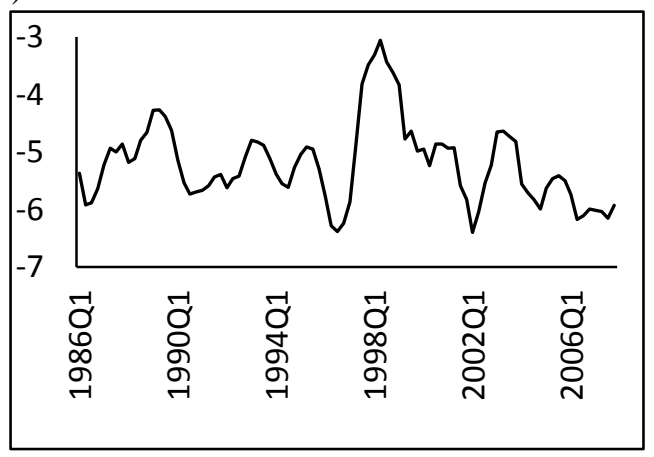

(b) FD

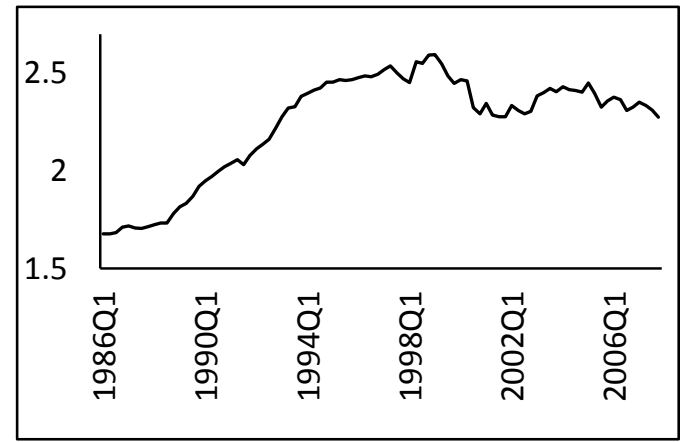

(d) FR

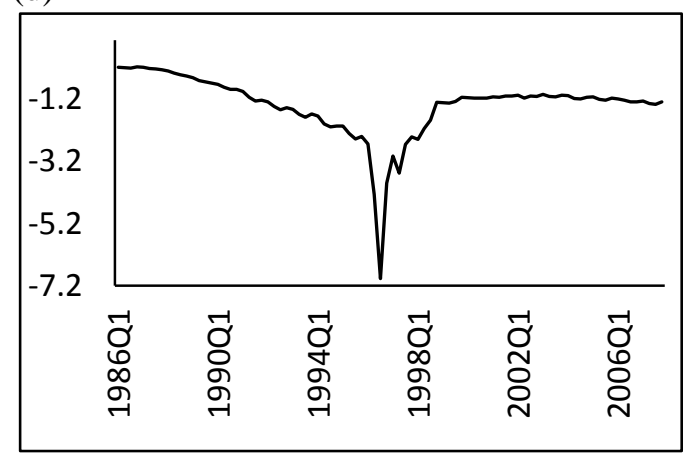

\section{Copyright Disclaimer}

Copyright reserved by the author(s).

This article is an open-access article distributed under the terms and conditions of the Creative Commons Attribution license (http://creativecommons.org/licenses/by/3.0/). 